\title{
Detection of cytomegalovirus antigens in phagocytosed serum complexes from a patient with rheumatoid arthritis, vasculitis, peripheral neuropathy, cutaneous ulceration, and digital gangrene
}

\author{
J N McCormick, D Wojtacha, E Edmond*
}

\begin{abstract}
A patient with rheumatoid arthritis, vasculitis, peripheral neuropathy, cutaneous ulceration, and digital gangrene was studied. Circulating immune complexes were detected by $\mathrm{Clq}$ binding although serum complement levels were within the normal range. Immunofluorescent staining of buffy coat cells with specific antisera showed the presence of IgG and IgM in phagocytosed inclusions but complement C3 was not detected. A monoclonal antibody specific for cytomegalovirus detected antigens in phagocytosed inclusions on one occasion. These results may suggest that cytomegalovirus antigens are a hitherto unidentified component of serum complexes in patients with rheumatoid arthritis and may contribute to the pathogenesis of the vasculitic complications of rheumatoid arthritis by participating in immune complex formation.
\end{abstract}

\section{Case report}

A 59 year old woman who had had seropositive rheumatoid arthritis for 30 years was admitted to the Northern General Hospital, Edinburgh with gangrene of the distal third of both thumbs. She also had paraesthesia and numbness in her hands and feet, which had developed three months previously. This had been preceded by marked vasospasm in her thumbs and the
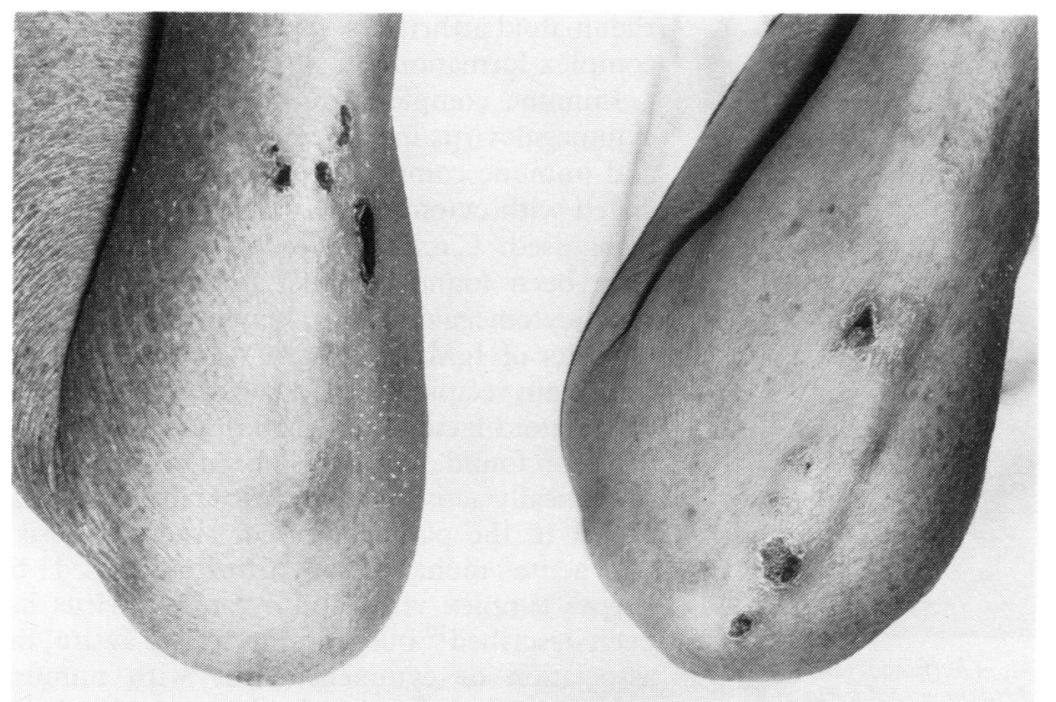

Figure 1 Cutaneous ulcers on the extensor aspect of elbows and forearms. left middle finger. She had also developed scattered small cutaneous ulcers on her elbows and knees one month earlier. She had been receiving prednisolone $10 \mathrm{mg}$ daily for 12 years and had previously developed a rash when treated with sodium aurothiomalate (Myocrisin).

On examination there were multiple small vasculitic nailfold lesions and multiple ulcers on the extensor aspect of her elbows and forearms (fig 1) and on her knees. There was also frank gangrene of the distal third of her thumbs (fig 2). There was cyanotic discolouration of her left middle finger and blunting of sensation in a glove and stocking distribution. There was no motor weakness. Her arthritis was widespread, but only moderately active.

\section{LABORATORY INVESTIGATIONS}

The following laboratory results were found: haemoglobin $151 \mathrm{~g} / \mathrm{l}$; white blood cell count $26 \times 10^{9} / 1$ with $89 \%$ neutrophils; platelets $842 \times 10^{9} / 1$; erythrocyte sedimentation rate 28 $\mathrm{mm} /$ hour; Rose-Waaler titre 1/256; and antinuclear factor titre 1/128. Clq binding was 0.253 (>0.150 was positive). C3 and C4 levels were $1 \cdot 28$ and $0 \cdot 19 \mathrm{~g} / \mathrm{l}$, respectively, and CH50 was $65 \mathrm{U} / \mathrm{ml}$ (table).

Fresh heparinised blood $(10 \mathrm{ml})$ was incubated at $37^{\circ} \mathrm{C}$ for 30 minutes and the buffy coat cells were separated by centrifugation at $800 \mathrm{rev} / \mathrm{min}$ for 15 minutes. Cytosmears were prepared and staining with fluorescein isothiocyanate (FITC)labelled antisera showed IgG and IgM in phagocytosed inclusions; C3 was not detected. The cytosmears were also treated with a mouse

Variation in C1q binding activity and complement levels with time

\begin{tabular}{|c|c|c|c|c|}
\hline \multirow{2}{*}{$\begin{array}{l}\text { Days of } \\
\text { illness }\end{array}$} & \multirow{2}{*}{$\begin{array}{l}\text { Clq binding } \\
\text { activity }\end{array}$} & \multicolumn{3}{|c|}{ Complement levels } \\
\hline & & $\begin{array}{l}C 3 \\
(\mathrm{~g} / l)\end{array}$ & $\begin{array}{l}C 4 \\
(g / l)\end{array}$ & $\begin{array}{l}\text { CH5O } \\
(\mathrm{U} / \mathrm{ml})\end{array}$ \\
\hline $\begin{array}{r}1 \\
3 \\
24 \\
45 \\
59 \\
63 \\
78 \\
88 \\
97 \\
112 \\
119\end{array}$ & $\begin{array}{l}0.253^{*} \\
0 \cdot 180 \\
0 \cdot 182 \\
0 \cdot 184 \\
0 \cdot 178 \\
0 \cdot 106 \\
0 \cdot 130 \\
0 \cdot 166 \\
0 \cdot 190 \\
0.246 \\
0 \cdot 187\end{array}$ & $\begin{array}{l}1 \cdot 28 \\
1.17 \\
1.37 \\
1 \cdot 10 \\
0.93 \\
0 \cdot 85 \\
0 \cdot 89 \\
0.94 \\
1.43 \\
1 \cdot 15 \\
1.26\end{array}$ & $\begin{array}{l}0.19 \\
0.24 \\
0.18 \\
0.22 \\
0.13 \\
0.17 \\
0.20 \\
0.23 \\
0.25 \\
0.19 \\
0.25\end{array}$ & $\begin{array}{l}65 \\
59 \\
34 \\
37 \\
64 \\
49 \\
55 \\
56 \\
78 \\
60 \\
23\end{array}$ \\
\hline
\end{tabular}

${ }^{*} \mathrm{CMV}$ antigens detected in phagocytosed inclusions. Normal values: $\mathrm{CH} 50,50-150 \mathrm{u} / \mathrm{ml} ; \mathrm{C} 3,0.76-1.60 \mathrm{~g} / \mathrm{l} ; \mathrm{C} 4$ $0 \cdot 20-0 \cdot 65 \mathrm{~g} / \mathrm{l}$; and Clq binding, $0 \cdot 130-0 \cdot 190$. 


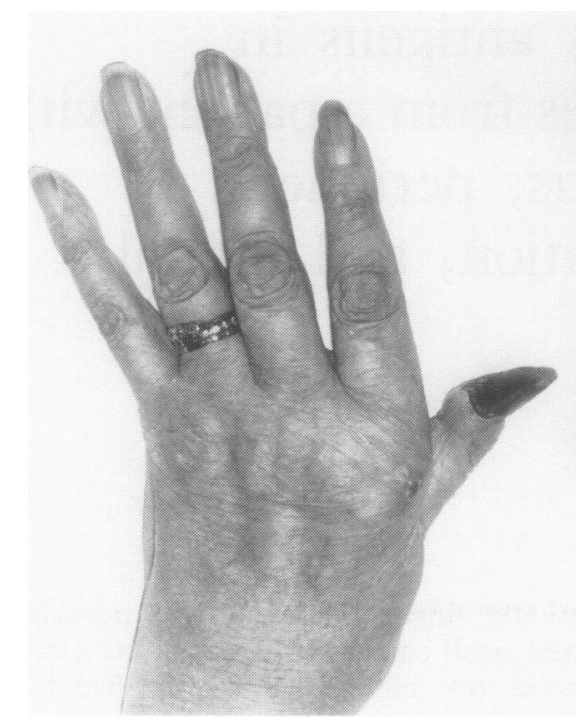

Figure 2 Gangrene of the distal third of thumbs.

monoclonal antibody specific for cytomegalovirus and stained with FITC labelled rabbit antimouse IgG antiserum. This technique stained the phagocytosed inclusions, indicating the presence of cytomegalovirus antigens (fig 3). When this examination was repeated at intervals over the next four months, cytomegalovirus antigen could no longer be detected, although circulating immune complexes could still be detected by $\mathrm{Clq}$ binding assay. Two attempts to isolate cytomegalovirus from buffy coat cells were unsuccessful.

\section{TREATMENT AND PROGRESS}

The dose of prednisolone was increased to 20 $\mathrm{mg}$ daily and penicillamine $750 \mathrm{mg}$ daily and isoxsuprine $40 \mathrm{mg}$ twice daily were added. Infection of the skin ulcers was treated with flucloxacillin.

The vasospasm subsided and the cutaneous ulcers slowly healed. Six weeks later the dose of prednisolone was reduced to $17 \cdot 5 \mathrm{mg}$ daily with further gradual reductions in dose to $10 \mathrm{mg}$ daily over the next four weeks.

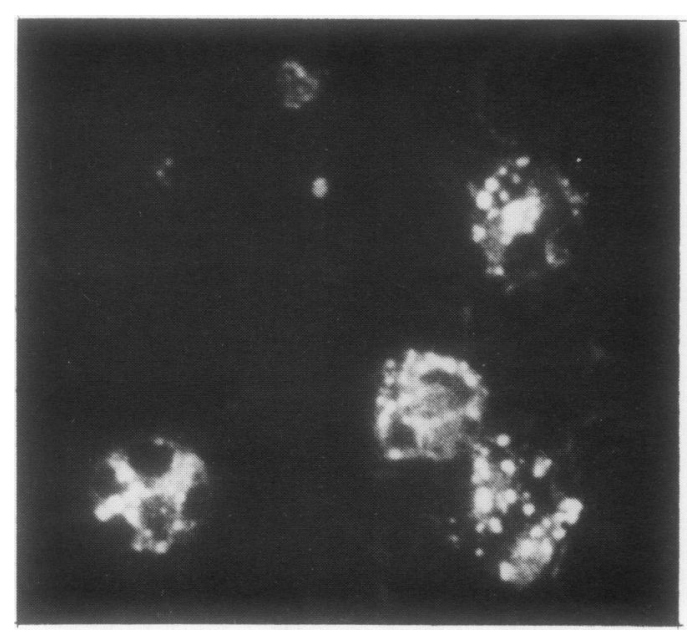

Figure 3 Fluorescent inclusions in buffy coat cells treated with mouse monoclonal antibody to cytomegalovirus and stained with fluorescein isothiocyanate labelled rabbit antimouse IgG.
Four months after admission, the patient was discharged home while receiving $10 \mathrm{mg}$ prednisolone and $750 \mathrm{mg}$ penicillamine daily. The ulcers had healed and there was demarcation of the gangrenous zones of her thumbs. The sloughs separated from her thumbs three months later and she was well apart from residual numbness and paraesthesia in her hands and feet.

\section{Discussion}

Vasculitis is not uncommon in rheumatoid arthritis. It may vary in extent from minor nailfold lesions to a full blown syndrome with peripheral neuropathy, cutaneous ulceration, and digital gangrene, as in this patient. An association between circulating immune complexes and vasculitis, as well as with other extraarticular features of rheumatoid arthritis, such as subcutaneous nodules and fibrosing alveolitis, has been reported. ${ }^{1-3}$

Analysis of such complexes has been undertaken and, in general, only serum proteins such as immunoglobulins, complement, albumin, and acute phase reactants have been identified. ${ }^{4}$ Melsom et al, however, also detected an unidentified 48 kilodalton polypeptide component in isolated serum complexes in vasculitic patients with rheumatoid arthritis by sodium dodecyl sulphate polyacrylamide gel electrophoresis and western blotting, which they thought might represent an exogenous antigen. ${ }^{4}$ In our laboratory an antiserum was raised against serum complexes by incubating rabbit buffy coat cells with serum samples from vasculitic patients with rheumatoid arthritis to allow phagocytosis of complexes and then injecting the cells back into the donor rabbits. This antiserum detected an unidentified component in most of the serum samples examined, which was associated with $\operatorname{IgM}$ rheumatoid factor by immunodiffusion analysis in agarose plates and reacted with cytomegalovirus infected HEF cells (McCormick, unpublished data). These observations suggest that cytomegalovirus antigens may be a hitherto unidentified component of serum complexes in patients with rheumatoid arthritis and may contribute to the pathogenesis of the vasculitic complications of rheumatoid arthritis by participating in immune complex formation.

Immune complexes in congenital and natal cytomegalovirus infections have been recorded ${ }^{5}$ and immune complex glomerulonephritis associated with cytomegalovirus infection has been recognised. ${ }^{6}$ Circulating IgM immune complexes have been found in renal transplant patients with cytomegalovirus infection. ${ }^{7}$ Perivascular deposits of IgM have been seen in skin from transplant recipients and a correlation with $\operatorname{IgM}$ rheumatoid factor and IgM immune complexes has been found. ${ }^{8}$ It has also been suggested that periodically activated cytomegalovirus may play a part in the pathogenesis of atherosclerosis. ${ }^{9}$ An acute monarticular arthritis caused by herpes simplex virus and cytomegalovirus has been described ${ }^{10}$ but, as far as we are aware, the association of cytomegalovirus with immune complexes and vasculitis in rheumatoid arthritis has not been reported previously. 
The disappearance of cytomegalovirus antigens after their original detection whereas circulating immune complexes were still detectable by $\mathrm{Clq}$ binding assay may suggest that this exogenous cytomegalovirus material was an irrelevant component of the serum complexes in this patient, though the possibility that cytomegalovirus infection was the event which initiated the generation of immune complexes cannot be ignored. Furthermore, a second patient with rheumatoid arthritis and vasculitis has been found whose phagocytosed serum complexes also contained cytomegalovirus antigens as determined by immunofluorescence. Further work on a larger group of patients with rheumatoid arthritis and vasculitis is planned.

1 Bourke B E, Moss I K, Mumford P A, Horsfall A C, Maini $\mathrm{R} N$. The complement fixing ability of putative circulating complexes in rheumatoid arthritis and its relationship to extra-articular disease. Clin Exp Immunol 1982; 48: 726-32. 2 Erhardt C C, Mumford P, Maini R N. The association of cryoglobulinaemia with nodules, vasculitis and fibrosing alveolitis in rheumatoid arthritis and their relationship to serum binding activity and rheumatoid factor. Clin Exp Immunol 1979; 38: 405-13.

3 Gierrson A J, Sturfelt G, Truedsson L. Clinical and serological features of severe vasculitis in rheumatoid arthritis: prognostic implications. Ann Rheum Dis 1987; 46: 727-33.

prognostic implications. Ann Rheum Dis 1987; 46: 727-33.
4 Melsom R D, Smith P R, Maini R N. Demonstration of an Melsom R D, Smith P R, Maini R N. Demonstration of an
unidentified $48 \mathrm{kD}$ polypeptide in circulating immune unidentified $48 \mathrm{kD}$ polypeptide in circulating immune
complexes in rheumatoid arthritis. Ann Rheum Dis 1987; 46: $104-9$.

5 Stagno S, Volanakis J E, Reynolds D W, Stroud R, Alford $\mathrm{C} A$. Immune complexes in congenital and natal cytomegalovirus infections of man. $\mathcal{f}$ Clin Invest $1977 ; 60$ : $838-45$.

6 Ozawa T, Stewart J A. Immune-complex glomerulonephritis associated with cytomegalovirus infection. $\mathrm{Am} f \mathrm{f}$ Clin Pathol 1979; 72: 103-7.

7 Baldwin W M, Van Es A, Valentijn R M, van Gemert G W, Daha M R, Vanes L A. Increased IgM and IgM immune complex-like material in the circulation of renal transplant recipients with primary cytomegalovirus infections. Clin Exp Immunol 1982; 50: 515-24.

8 Baldwin W H, Westedt H L, Vermeer B J, et al. Perivascular deposits of IgM in the skin of transplant recipients during deposits of IgM in the skin of transplant recipients during
active cytomegalovirus infections. Correlation with IgM active cytomegalovirus infections. Correlation with IgM rheumatoid factors and IgM

9 Adam E, Probstfield J L, Buick J, et al. High levels of cytomegalovirus antibody in patients requiring vascular surgery for atherosclerosis. Lancet 1987; ii: 291-3.

10 Friedman $\mathrm{H}$ M, Pincus T, Gibilisco P, et al. Acute monoarticular arthritis caused by herpes simplex virus and cytomegalovirus. Am $\mathcal{Y}$ Med 1980; 69: 241-7. 